\title{
Non-White Migration, Welfare Levels, And The Political Process: Some Additional Results
}

\author{
Robert Premus and Robert Weinstein*
}

\section{Introduction}

In a recent article, Richard Cebula (5) presented an interesting model of the simultaneous determination of black interstate net migration rates and welfare level changes over the 1960 to 1970 period. His two-stage least squares test found support for the two-pronged hypothesis that the change in welfare benefit levels among states is influenced by the political behavior (the vote) of black migrants and that these changes in welfare benefit levels, in turn, influence the pattern of black migration among the states. According to Cebula, his findings suggest that:

". . . areas with "high" welfare benefits are likely to attract those segments of the population interested in receiving such benefits and, over time, these segments are likely to worsen the financial problems in these areas (states and/or cities) by exerting political pressure (the vote) for higher benefit levels. Both of these observations imply the need for a uniform (standardized) welfare system throughout the United States." (5, p. 119)

Due to problems of model specification and identification, the results of Cebula's test and his conclusions are questionable. Therefore, the purpose of this paper is to correct the specification and identification errors found in Cebula's paper and to provide an alternative test of the simultaneity hypothesis. Section II discusses the limitations of Cebula's twopronged test and presents an alternative specification of the model. The test results, which are presented in Section III, are substantially different from Cebula's results. In particular, blacks were found not to be responsive to welfare level changes when formulating migration decisions. Thus, the two-pronged hypothesis cannot be supported; although, support is found for the hypothesis that growth in welfare payments and black migration behavior are both positively influenced by the growth in income making it appear that they are jointly determined. The final section includes a summary and a discussion of the conclusions of our analysis.

\footnotetext{
*We wish to thank the three anonymous referees of this Journal for their many helpful comments. The authors, of course, assume full responsibility for any errors that may appear in the paper. Both authors are members of the Department of Economics, Wright State University, Dayton, Ohio.
} 


\section{Model Specification}

Cebula presented the following simultaneous equation model:

(1) $\mathrm{M}_{\mathrm{i}}=\mathrm{a}_{0}+\mathrm{a}_{1} \mathrm{~W}_{\mathrm{i}}+\mathrm{a}_{2} \mathrm{U}_{3}+\mathrm{a}_{3} \mathrm{Y}_{\mathrm{i}}+\mathrm{a}_{4}$

(2) $\mathrm{W}_{\mathrm{i}}=\mathrm{b}_{0}+\mathrm{b}_{1} \mathrm{M}_{\mathrm{i}}+\mathrm{b}_{2} \mathrm{U}_{\mathrm{i}}+\mathrm{b}_{3} \mathrm{I}_{\mathrm{i}}+\mathrm{b}_{4}$

where: $a_{0}, b_{0}=$ constants

$a_{4}, b_{4}=$ error terms

$\mathrm{M}_{\mathrm{i}}=$ net nonwhite in-migration rate to state $\mathrm{i}, 1960-1970$

$\mathrm{W}_{\mathrm{i}}=$ growth in welfare benefits per recipient in state $\mathrm{i}$ over the period

$\mathrm{U}_{\mathrm{i}}=$ average unemployment rate in state $\mathrm{i}, 1960$

$\mathrm{Y}_{\mathrm{i}}=$ per capita income in state $\mathrm{i}, 1960$

$I_{i}=$ median income in state $i, 1960$

One problem of model specification found in Cebula's test concerns his use of total rather than race specific measures of income and unemployment in the migration equation. Since the major focus of his paper is on the migration and political behavior of blacks, and since per capita measures of income and unemployment may seriously misrepresent the actual labor market opportunities available to blacks, the use of race specific measures of these variables in the migration equation would seem to be necessary and relevant. This view is supported in an earlier paper in which Cebula (6) criticized Sommers and Suits (S \& S) (17) for their failure to use race specific measures in their single equation test of the influence of 1960 welfare benefit levels on 1960-70 interstate migration rates of nonwhites. Cebula's respecification of the $\mathrm{S} \& \mathrm{~S}$ model found that the use of race specific data significantly modified the results of the test. The S \& S model found black migrants to be weakly responsive to initial welfare levels and strongly responsive to total per capita income; whereas, Cebula's respecification found interstate nonwhite migration rates to be strongly responsive to welfare levels and weakly responsive to race specific income levels. Certainly, if the relationship between welfare levels, income, and black migration rates are sensitive to the choice of race specific measures of these variables, then their inclusion in a test of the simultaneity hypothesis is appropriate.

A second specification problem in the migration equation results from the omission of changes in black income over the migration period as an explanatory variable. The "life cycle approach" suggests that current income does not adequately measure the expected returns to migration. In fact, Cebula and Vedder (8, p. 25) concluded that income expectations (measured by the change in income over the period) "for the most part, have had a significant influence on interstate migration in the United States." However, no explanation was provided by Cebula in his test of 
the simultaneity (two-pronged) hypothesis for the omission of race specific income changes as a determinant of black migration behavior.

Third, Cebula omitted several other variables from his migration equation which he had found to be significant determinants of black migration in still other papers. These other variables include measures of state racial composition and state temperature levels.

The identification problem found in Cebula's test results from his use of median family income in 1960 as the exogenous variable to identify the influence of welfare level changes on black migration, and his use of per capita income in 1960 to identify the relationship between welfare change and black migration behavior in the welfare change equation. Although both equations are technically identified, the choice of these particular variables is unfortunate since they reflect the same exogenous influences. ${ }^{1}$ To the extent that these two variables do reflect similar influences, neither of Cebula's equations are identified, and, therefore, the results presented are spurious.

Finally, in addition to the identification problem, Cebula's welfare change equation may suffer from several specification errors. First, income change would seem to be more relevant in explaining the growth in welfare payments than beginning-of-period, median family income. Second, demographic differences among the states (e.g., the distribution of household heads by sex) undoubtedly contribute to the willingness of states to supply welfare services, but demographic variables are noticeably absent in Cebula's model.

To overcome some of the problems of Cebula's test, we specify an alternative state level model which is presented as follows:

(3) $\mathrm{X}_{1}=\mathrm{t}\left(\mathrm{X}_{2}, \mathrm{X}_{3}, \mathrm{X}_{4}, \mathrm{X}_{5}, \mathrm{X}_{6}, \mathrm{X}_{7}\right)$

(4) $X_{2}=t\left(X_{1}, X_{8}, X_{9}, X_{10}\right)$

where:

$\mathrm{X}_{1}=$ net migration rate of blacks, 1960-1970;

$\mathrm{X}_{2}=$ change in monthly aid per family with dependent children, 1965-1970;

$\mathrm{X}_{3}=$ change in black median family income, 1960-1970;

$\mathrm{X}_{4}=$ black unemployment rate, 1960;

$\mathrm{X}_{5}=$ net migration rate of blacks, 1950-1960;

$\mathrm{X}_{6}=$ median family income of blacks, 1959;

$\mathrm{X}_{i}=$ normal monthly average temperature, 1941-1971;

$\mathrm{X}_{8}=$ total unemployment rate, 1960;

$\mathrm{X}_{9}=$ change in percentage female heads of households, 1960-1970; and

$\mathrm{X}_{10}=$ change in per capita income, 1960-1970. 
The model is similar to Cebula's model in that black net migration rates and changes in the level of welfare payments are viewed as interdependent phenomenon. However, unlike Cebula's model, race specific income, income changes, and unemployment measures, as well as measures of interstate differences in climatic conditions and racial factors, are incorporated into the migration equation to provide a more properly specified model.

In equation (3), the migration equation, the change in welfare payments $\left(\mathrm{X}_{2}\right)$ is viewed as a determinant of black migration behavior. Black migrants are presumed to respond positively to the growth in welfare payments on the assumption that they are net beneficiaries of welfare programs; i.e., in the aggregate the black population expects to receive welfare payments in excess of the share of their tax contributions that are used to finance welfare programs. Black median family income in 1960 $\left(\mathrm{X}_{3}\right)$, the change in black median family income $\left(\mathrm{X}_{4}\right)$ and the black unemployment rate in $1960\left(\mathrm{X}_{5}\right)$, on the other hand, are included in the migration equation to capture the influence on interstate differences in expected labor market opportunities available to black migrants. The expected signs of their co-efficients are positive, positive and negative respectively.

Also, we hypothesize that the black migrant is more likely to choose a location that earlier black migrants found to be attractive. This "migrant stream" hypothesis is justified on the basis of imperfect informational flows and/or "family-friends" effects. We hypothesize that those states which experienced higher rates of net black migration from 1950 to 1960 $\left(\mathrm{X}_{6}\right)$ will experience, other things equal, higher 1960-1970 migration rates.

Finally, normal average temperature $\left(\mathrm{X}_{7}\right)$ is incorporated into the migration equation to capture the observed net shift in the black migrant population from the southern to the northern and western states. Cebula included a similar variable in his version of the $\mathrm{S} \& \mathrm{~S}$ model, and like Cebula, we hypothesize a negative relationship between temperature and black migration flows.

Equation (4) is used to explain changes in welfare levels among the states. Variable $\mathrm{X}_{1}$, black net migration rates, is incorporated as an explanatory variable to test the hypothesis that the supply of welfare services available within a state is the outcome of political processes that are influenced by the 1960-1970 black migrant population. Higher black net migration rates reflect more potential favorable welfare votes via the ballot box; thus, a positive regression coefficient for $\mathrm{X}_{1}$ is postulated. Also, the 1960 aggregate unemployment rate $\left(\mathrm{X}_{8}\right)$ is used in equation (4) as a proxy for the number of persons with a zero wage alternative. Thus, states with higher levels of unemployment are expected to experience additional political pressures to offer higher levels of welfare benefits. $\mathrm{X}_{9}$, the change in the percentage of female heads of families, captures interstate differentials in demographic factors that may influence changes in welfare levels. A positive value for variable $\mathrm{X}_{9}$ reflects an increase in 
both the potential supply of welfare recipients and the number of votes favorable to increases in welfare levels. The former influence is likely to reduce the per capita increase in welfare payments since an increase in a state's welfare budget must be spread over a larger number of recipients. The latter influence, however, will act to raise welfare payments per recipient because political support for higher levels of welfare payments will be enhanced. Since the relative importance of these divergent influences cannot be determined on a priori grounds, the expected sign $\mathrm{X}_{9}$ is indeterminant. ${ }^{2}$ Finally, since variable $\mathrm{X}_{10}$ (per capita income change) is expected to be directly related to the change in welfare benefits, a positive sign for $\mathrm{X}_{10}$ is anticipated.

Our sample consists of all states with the exception of Alaska and Hawaii. The data for $\mathrm{X}_{1}, \mathrm{X}_{2}, \mathrm{X}_{7}$, and $\mathrm{X}_{10}$ were obtained from the $U$. $S$. Statistical Abstract, 1972 (22, Tables 29, 490, 295, and 519). The data for $\mathrm{X}_{4}, \mathrm{X}_{6}$, and $\mathrm{X}_{8}$ were taken from the U. S. Census of Population, 1960 (19, Tables 46 and 65). Variables $\mathrm{X}_{3}$ and $\mathrm{X}_{9}$ were computed from data obtained from the 1960 and 1970 volumes of the U. S. Census of Population (19, Tables 65, 106 and 110; and 20, Tables 57 and 65). Finally, variable $\mathrm{X}_{5}$ was drawn from the U. S. Statistical Abstract, 1966 (21, T'able 35).

\section{The Results}

The results of our two-stage least squares test are presented in equations (5) and (6) as follow (t values are in parentheses):

$$
\begin{aligned}
& \text { (5) } \mathrm{X}_{1}=-20.1655+.1049 \hat{\mathrm{X}}_{2}+.0038 \mathrm{X}_{3}-3.547 \mathrm{X}_{4} \\
& \text { (.680) (1.822) (.071) } \\
& +.1102 \mathrm{X}_{5}+.0101 \mathrm{X}_{6}-.3302 \mathrm{X}_{7} \\
& \text { (1.849) (6.008) (.686) } \\
& \text { Adjusted } \mathrm{R}^{2}=.72 \\
& \mathrm{df}=41 \\
& \mathrm{~F}=21.03 \\
& \text { (6) } \mathrm{X}_{2}=-38.302+0.626 \hat{\mathrm{X}}_{1}+326.180 \mathrm{X}_{8}-92.679 \mathrm{X}_{9}+.049 \mathrm{X}_{10} \\
& \text { (2.238) (.871) (3.315) } \\
& \text { Adjusted } \mathrm{R}^{2}=.34 \\
& \mathrm{df}=43 \\
& \mathrm{~F}=7.09
\end{aligned}
$$

The coefficient for welfare change in the migration equation in our test, which was found to be statistically insignificant at the five percent level, is at odds with Cebula's findings. Thus, no support is found for the hypothesis that interstate black migration patterns are influenced by differentials in the growth of welfare payments among the states. On the other hand, the coefficient for the level and change in the median family in- 
come of blacks, variables $\mathrm{X}_{6}$ and $\mathrm{X}_{3}$ respectively, are statistically significant at the five percent level. The income level also entered as a significant migration determinant in Cebula's paper. Also, the positive and statistically significant coefficient for variable $\mathrm{X}_{5}$, the 1950-1960 black migration rate, provides some support for the "migrant stream" hypothesis. Finally, variables $\mathrm{X}_{7}$, a proxy for the net shift in the black population, from warmer to colder states, and $\mathrm{X}_{4}$, the 1960 black unemployment rate, were found to be statistically insignificant at a reasonable level of significance. Overall, the migration equation explains 71 percent of the interstate variance in black net migration rates, and it is statistically significant at the one percent level $(\mathrm{F}=21.03)$.

In general, equation (5) suggests that black migrants are more sensitive to the level and growth in income opportunities than they are to growth in welfare payments in formulating migration decisions. Studies by DeJong and Donnelly (9), Pack (16), and Sommers and Suits (17) support this finding, but it is at odds with Cebula's version of the S \& S model (6). Also, our finding in support of the "migrant stream" hypothesis is consistent with the findings of Pack (16) and Greenwood (14), but is at odds with the results presented by DeJong and Donnelly (9). ${ }^{3}$ The insignificance of the temperature variable in our test is inconsistent with studies by Cebula and Vedder (7), Galloway (11), and Greenwood (13). Finally, the insignificance of the unemployment variable suggests that the black migrants may be, in general, the better educated and employable members of the black population. This would also explain why welfare change did not enter significantly in the migration equation since the black migrants, in general, would not be directly concerned with their nonwage alternatives. ${ }^{4}$

The welfare change equation explains 46 percent of the growth in welfare payments among the states. The statistically significant coefficient for variable $\mathrm{X}_{1}$ is consistent with Cebula's conclusion that the black migrants contribute to intrastate political pressures (by the vote) to raise welfare payment levels. This possibly reflects the egalitarian preferences of black migrants for less income inequality. The coefficient for $\mathrm{X}_{9}$, percentage change in female heads of households, is negative and is statistically significant at the five percent level. Its negative sign suggests that the growth in potential welfare recipients, other things equal, primarily acts to discourage state legislatures from offering larger increases in welfare payments per recipient. The coefficient for the change in total per capita income, $\mathrm{X}_{10}$ is, as expected, positive and statistically significant at the five percent level. Other things equal, states which are experiencing greater increases in affluence are the states which offer greater increases in welfare payments. Finally, the total unemployment rate for $1960, \mathrm{X}_{8}$, is not statistically significant at a reasonable level although it does display the expected sign.

When equations (5) and (6) are considered jointly, the results suggest that states with higher income growth (1) attract larger numbers 
of black migrants and (2) offer higher levels of welfare payments. Rather than being interdependent phenomena-as Cebula suggested-both of these factors reflect their dependence on the level and growth of income by state; i.e., blacks are attracted to states with the highest potential for a significant improvement in their income position and the indigenous population in these same states are willing to share their greater affluence by offering higher welfare levels. Those states with higher income induced black net in-migration rates, on the other hand, were found to experience additional political pressures to offer higher levels of welfare payments. But these income and political induced increases in welfare payments do not by themselves attract additional black migrants to these states. ${ }^{5}$ Thus, an important distinction in our test in contrast to Cebula's findings is that the observed increased concentration of blacks in high income states is not induced by the more rapid growth in welfare payments in these states.

\section{Summary and Conclusions}

This paper extended Cebula's model of the simultaneous determination of welfare level changes and the net migration patterns of blacks and found substantially different results. In particular, no statistical support was found for the simultaneity hypothesis; namely, that black migrants are being lured to those states which experience greater increases in welfare payments levels, and after they become residents the black migrants exert political pressures (via vote) on state legislatures to offer even higher welfare payments levels. In particular, the income level, the change in income, and the migration decision of former black migrants were found to be the primary determinants of interstate black net migration flows. Although increases in the levels of welfare payments were found not to attract black migrants, support was found for the hypothesis that states which experience higher positive net black migration rates will also experience political pressures to offer higher levels of welfare services. In addition, the growth in welfare payments per recipient was found to be positively influenced by the growth in affluence (total per capita income) and negatively related to the number of potential welfare recipients. The total unemployment rate was found to have no bearing on the growth of welfare payments by states.

In conclusion, our analysis leads to a different set of policy recommendations. Cebula suggested that a uniform system of welfare payments (e.g., a negative income tax) may be necessary to remove the distorting effects of welfare payments differentials on black migration flows among the states. While this may have appeal on ethical grounds, our analysis suggests that there is no efficiency argument for this conclusion. In fact, there may be an efficiency argument in favor of allowing states to determine their respective welfare payments levels, as in the case of other public services, in accordance with the preferences of their citizens. Nonetheless, even under a system of uniform welfare payment levels 
among the states, our analysis suggests that the tendency of increasing concentrations of blacks in the high income states would be expected to continue. If their presence creates negative fiscal externalities (e.g., higher levels of welfare payments that usurp public funds from other public expenditures programs), an interstate system of equalizing grants, as suggested by Buchanan and Wagner (4) and Buchanan and Goetz (3), may be the more appropriate corrective mechanism.

\section{FOOTNOTES}

1 For example, the simple correlation coefficient between these two variables in 1970 was .65 in our test.

2To an extent, the sign of the coefficient for variable $X_{1}$ may also be indeterminant. $X_{1}$, like $X_{\theta}$, represents an increase in the potential supply of welfare recipients and an increase in potential support for higher levels of welfare payments. Nevertheless, we hypothesize a positive sign for $\mathrm{X}_{1}$ on the assumption that the latter influence dominates.

3. An important distinction in our test is that we emphasize the "migrant stream" hypothesis in contrast to the "migrant stock" relationship tested by Fabricant (10), Greenwood (14) and DeJong and Donnelly (9). The "migrant stream" is measured by a one period lag in black migration flows; whereas, the "migrant stock" is the sum of all previous period migration flows plus the original indigenous black population expressed as a percentage of the total population (i.e., the percentage non-white population). As Greenwood pointed out, the "migrant stock" variable may be picking up some of the influence of the other migration determinants, thus biasing their regression coefficients. The "migrant stream" variable should correct for this to an extent since it only reflects the recent addition to the total migrant stock. In any case, the coefficients and standard errors of the other variables were not significantly affected by deleting $X_{5}$ from the migration equation, suggesting that multi- collinearity was not a serious problem.

${ }^{4}$ The view that black migrants stand to gain the most from welfare programs-which is central to Cebula's assumption that the black migrant population will be attracted to those states offering high levels of welfare benefitsmay be misleading. Studies by Masters (15), Berry (2), Adams and Estelle (1) and Treacy (18) find evidence that the black migrant population is substantially more educated and affluent than the indigenous black population of the state to which they migrate. Also, the presence of relatively high income blacks in the migrant stream would suggest that these individuals may be repulsed by high welfare benefits and welfare changes because their share of the benefits would be less in proportion to their contribution to the revenues which finance the welfare programs. Both of these factors should act to reduce any observed statistical relationship between welfare benefit changes and the rate of black interstate net migration.

"The simple correlation coefficient relating $\mathrm{X}_{::}$and $\mathrm{X}_{10}$ is 46 , indicating that some multi-

collinearity may exist between $\mathrm{X}_{10}$ and $\hat{\mathrm{X}}_{1}$ in the welfare change equation- $\mathrm{X}_{3}$ was found to be a determinant of $\mathrm{X}_{1}$ in the migration equation. To the extent that multicollinearity exists, the coefficients for $\mathrm{X}_{3}$ and $\mathrm{X}_{10}$ are biased, and our support for Cebula's hypothesis that black migrants engage in political activities to raise welfare levels is weakened.

\section{REFERENCES}

1. Adams, A. V. and Nestel, G. "Interregional Migration, Education and Poverty in the Urban Ghetto: Another Look at BlackWhite Earnings Differentials," Review of Economics and Statistics, Vol. 58, May 1976, pp. 156-66.

2. Berry, R. A. "Impact of Factor Emigration on the Losing Region," The Economic Record, September 1974, pp. 405-22.

3. Buchanan, J. M. and Goetz, C. J. "Efficiency Limits of Fiscal Mobility: An Assessment of Fiscal Mobility: An Assessment of the Tiebout Model," Journal of Public Economics, Vol. 1, 1972, pp. 25-43.

4. Buchanan, J. M. and Wagner, R. E. "An Efficiency Basis for Federal Fiscal Equalization," in Margolis, Julius, ed. The Analysis of Public Output. New York: Columbia University Press, 1970.
5. Cebula, R. J. "A Note on Nonwhite Migration, Welfare Levels, and the Political Process," Public Choice, Volume XXVIII, Winter, 1976, pp. 117-119.

6. Cebula, R. J. "Analysis of Net Interstate Migration: Comment," Southern Economic Journal, April, 1975, pp. 690-693.

7. Cebula, R. J. and Vedder, R. K. "A Note on Migration, Economic Opportunity, and the Quality of Life," Journal of Regional Science, Volume 13, no. 2, 1973, pp. 205211.

8. Cebula, R. J. and Vedder, R. K. "An Empirical Analysis of Income Expectations and Interstate Migration," Review of Regional Studies, Volume 5, no. 1, pp. 19-28.

9. DeJong, G. F. and Donnelly, W. L. "Public Welfare and Migration," Social Science 
Quarterly, September 1973, 54(2), pp. 32944.

10. Fabricant, R. A. "An Expectational Model of Migration," Journal of Regional Science, April 1970, 10(1), pp. 13-24.

11. Galloway, L. E. "Age and Labor Mobility Patterns," Southern Economic Journal, Vol. 36, October 1969, pp. 171-180.

12. Greenwood, M. J. "A Simultaneous-Equations Model of White and Nonwhite Migration and Urban Change," Economic Inquiry, Vol. XIV, March 1976, pp. 1-15.

13. Greenwood, M. J. "An Analysis of the Determinants of Geographic Labor Mobility in the United States," Review of Economics and Statistics, Vol. 51, May 1969, pp. 189-194.

14. Greenwood, M. L. "Lagged Response in the Decision to Migrate: A Reply," Journal of Regional Science, August 1972 12(2), pp. 311-24.

15. Masters, S. H. "Are Black Migrants from the South to the Northern Cities Worse Off Than Blacks Already There?" Journal of Human Resources, Vol. 7, Fall 1972, pp. 411-23.

16. Pack, J. R. "Determinants of Migration to Central Cities," Journal of Regional Science, August 1973, 13(3), pp. 249-60.

17. Sommers, P. M. and Suits, D. B. "An Analysis of Net Interstate Migration," Southern Economic Journal, October 1973, 40(2), pp. 193-201.

18. Treacy, J. J. "Characteristics of In-migrants to Ohio 1965-70: Implications for Education and Manpower Policy," presented at the Mid-West AIDS Conference, May 5-7, Cleveland, Ohio, 1977.

19. U. S. Bureau of the Census. U. S. Census of Population, 1960. General Social and Economic Characteristics, U. S. Summary and Related State Volumes. Washington, D. C.: U. S. G.P.O., 1963.

20. U. S. Census of Population, 1970. General Social and Economic Characteristics, U. S. Summary and Related State Volumes. Washington, D. C.: U. S. G.P.O., 1972.

21. Statistical Abstract of the United States, 1966. Washington, D. C.: U. S. G.P.O., 1976.

22. Statistical Abstract of the United States, 1972. Washington, D. C.: U. S. G.P.O., 1973. 